\title{
Real-Time Quantitative RT-PCR of Defense-Associated Gene Transcripts of Rhizoctonia solani-Infected Bean Seedlings in Response to Inoculation with a Nonpathogenic Binucleate Rhizoctonia Isolate
}

\author{
Kui Wen, Philippe Seguin, Marc St.-Arnaud, and Suha Jabaji-Hare
}

\begin{abstract}
First, second, and fourth authors: Plant Science Department, Macdonald Campus of McGill University, 21111 Lakeshore Rd., Sainte-Annede-Bellevue, Québec, H9X 3V9, Canada; and third author: Institut de Recherche en Biologie Végétale, Université de Montréal, and Jardin Botanique de Montréal, 4101, rue Sherbrooke est, Montréal, Québec, H1X 2B2, Canada. Accepted for publication 3 December 2004.
\end{abstract}

\begin{abstract}
Wen, K., Seguin, P., St.-Arnaud, M., and Jabaji-Hare, S. 2005. Real-time quantitative RT-PCR of defense-associated gene transcripts of Rhizoctonia solani-infected bean seedlings in response to inoculation with a nonpathogenic binucleate Rhizoctonia isolate. Phytopathology 95:345-353.

Certain isolates of nonpathogenic binucleate Rhizoctonia spp. (np$\mathrm{BNR}$ ) are effective biocontrol agents against seedling root rot and damping-off. Inoculation of bean seed with np-BNR strain 232-CG at sowing reduced disease symptoms in bean (Phaseolus vulgaris) seedlings caused by $R$. solani. Molecular analyses of the spatial expression of three defense-associated genes were carried out using real-time quantitative reverse transcription-polymerase chain reaction (QRT-PCR) assays. This

1- and 2-week-old bean seedlings that were inoculated simultaneously with np-BNR and infected with $R$. solani, and in seedlings that were singly inoculated with either fungi or not inoculated. In the seedlings that were infected with $R$. solani only, results revealed that, following infection, activation of all defense-associated gene transcripts was achieved with significant increases ranging from 7- to 40-fold greater than the control, depending on the defense gene and tissue analyzed. Seedlings that were treated with np-BNR and infected with $R$. solani had expression similar to those that were treated with np-BNR only, but the levels were significantly down-regulated compared with those that were infected with $R$. solani only. These findings indicate that disease suppression by np-BNR isolate is not correlated to $p G 101, g P A L 1$, and $C H S 17$ gene activation.
\end{abstract} method allowed accurate quantitative evaluation of transcript levels of $p G 101$ encoding for 1,3- $\beta$-D-glucanase, $g P A L 1$ encoding for phenylalanine ammonia lyase, and CHS17 encoding for chalcone synthase in
Additional keywords: biological control, induced systemic resistance, plant defense response.
Several studies have demonstrated protection of young seedlings of many crops against damping-off and crown and root rot diseases caused by Pythium Pringsh. spp. and Rhizoctonia solani Kühn with nonpathogenic binucleate Rhizoctonia spp. (np-BNR) belonging to the anastomosis groups AG-A, AG-B(a), AG-B(o), AG-G, AG-I, AG-K, and AG-P $(2,4,20,21,38,43)$. Induced resistance has been proposed as the plausible mechanism of np-BNR protection against $R$. solani in poinsettia cuttings (21), corn (29), soybean $(31)$, and bean $(22,46)$ in greenhouse studies. A biochemical study by Xue et al. (46) demonstrated that inoculation of the hypocotyl of etiolated bean seedlings (Phaseolus vulgaris L.) with the np-BNR isolate 232-CG (AG-G) elicited induced systemic resistance in the roots, crown, and cotyledons to later challenges with either the root rot pathogen $R$. solani (AG-4) or the foliar pathogen Colletotrichum lindemuthianum (Sacc. \& Magnus) Lams.-Scrib. In addition, the np-BNR elicited a significant and systemic increase in total peroxidases, $1,3-\beta$-glucanases, and chitinases compared with the diseased and control plants, and this increase was negatively correlated with disease incidence.

One type of induced resistance, called systemic acquired resistance (SAR), has been extensively studied and characterized (34). SAR is regulated by endogenous amounts of the systemic signal molecule, salicylic acid (SA) (34), and is effective against a broad spectrum of pathogens (19). It is an active process dependent on RNA and protein synthesis $(34,41)$. Pathogen attack and elicitors

Corresponding author: S. Jabaji-Hare; E-mail address: suha.jabaji-hare@mcgill.ca

DOI: 10.1094/PHYTO-95-0345

(C) 2005 The American Phytopathological Society of biotic and nonbiotic origins cause massive changes in the pattern of RNA synthesis, and these include transcriptional activation of defense-associated genes that encode cell wall hydroxyprolinerich-glycoproteins (HRGP), production of phytoalexins, and synthesis of pathogenesis-related (PR) proteins $(11,16,42)$.

Determining how np-BNR isolates affect defense-associated gene expression in bean is crucial to understanding this mechanism of bioprotection and, further, to lead to a more efficient use of these biocontrol agents. The recent development of real-time quantitative reverse transcription-polymerase chain reaction (QRTPCR) assays has allowed the accurate expression profiling of RNA transcripts, and has become the most useful method for characterizing gene expression in human research (3). Real-time QRT-PCR technology relies on the ability to progressively monitor fluorescence emitted from specific double-stranded DNA binding dye such as SYBR green I (25) or fluorophore-labeled probes that hybridize to target sequences during the exponential phase of the PCR reaction such that quantification is accomplished (28). Few reports have been published on the application of real-time QRTPCR in plants, to profile the spatio-temporal expressions of hormones in strawberry (1), and to estimate gene copy number in transgenic maize and soybean (26,39). This technology clearly has not yet been completely exploited in plant-microbe interaction studies. One study, by McMaugh and Lyon (28), reported on the application of real-time QRT-PCR to analyze the expression of class II chitinase in Bermudagrass following infection with the root pathogen Ophiosphaerella narmari.

The main objective of this study was to determine whether or not alteration in the spatial expression of plant defense-associated genes is a significant mechanism of disease suppression by np- 
BNR. Our goal was to apply real-time QRT-PCR technology to quantify transcript levels of defense-associated genes coding for 1,3- $\beta$-D-glucanases (GLUC), phenylalanine ammonia lyase (PAL), and chalcone synthases (CHS) in roots, stems, and leaves of 1and 2-week-old bean seedlings following infection with $R$. solani, and to compare them to levels estimated in tissues of np-BNR protected and infected or not infected with $R$. solani.

\section{MATERIALS AND METHODS}

Fungal cultures and inoculum preparation. A highly pathogenic isolate of $R$. solani AG-4 (A76) and np-BNR isolate 232CG were cultured on potato dextrose agar plates and grown at $24^{\circ} \mathrm{C}$ in the dark in an incubator for 1 week. The inocula for $R$. solani and np-BNR were prepared by inoculating $50 \mathrm{~g}$ of sterile oat kernels in 250-ml Erlenmeyer flasks with three plugs and incubated at $24^{\circ} \mathrm{C}$ for 3 weeks according to the method of Cardoso and Echandi (4). Colonized oat kernels were stored at $4{ }^{\circ} \mathrm{C}$ until further use. Sterile oat kernels were used as mock inoculum for the control treatment.

Plant material and inoculation. Bean seed (Phaseolus vulgaris) cv. Contender UT15 (Stokes Seeds Ltd., St. Catherines, $\mathrm{ON}$, Canada) were surface sterilized in $30 \% \mathrm{H}_{2} \mathrm{O}_{2}$ for $5 \mathrm{~min}$, rinsed with sterile distilled water, and then pre-germinated on filter papers for $48 \mathrm{~h}$ at $24^{\circ} \mathrm{C}$ in the dark in an incubator. Conetainers (Stuewe and Sons, Corvallis, OR) of 164-ml capacity were used to grow the plants. Prior to use, the Cone-tainers were surface sterilized for $45 \mathrm{~min}$ in $2.5 \%$ (wt/vol) $\mathrm{NaOCl}$ and rinsed with distilled water. A glass marble was inserted in each one to plug the drain hole, followed by the addition of $16 \mathrm{ml}$ of washed and autoclaved $65-\mathrm{mm}$ gravel and then $100 \mathrm{ml}$ of sand previously pasteurized for $1 \mathrm{~h}$ at $70^{\circ} \mathrm{C}$. Two pregerminated bean seeds and three oat kernels colonized with np-BNR 232-CG or noncolonized oat kernels (mock inoculum) were placed on the top of the sand depending on the treatment. The seed and oat kernels were covered with $30 \mathrm{ml}$ of pasteurized sand containing ground oat kernels $(0.5 \mathrm{~g} /$ liter $)$ previously colonized with $R$. solani A76 or mock inoculum, depending on the treatment. There were four treatments: (i) uninoculated control receiving mock inoculum (-B-R), (ii) inoculated with np-BNR isolate (+B-R), (iii) infected with $R$. solani isolate $(-\mathrm{B}+\mathrm{R})$, and (iv) inoculated with both $n p-$ $\mathrm{BNR}$ and $R$. solani isolates $(+\mathrm{B}+\mathrm{R})$. The treatments were arranged in a randomized complete block design with split-plot restriction and three replicates. The harvesting weeks ( 1 and 2 weeks after seeding) were randomized among the main plots whereas the four inoculation treatments $(-\mathrm{B}-\mathrm{R},+\mathrm{B}-\mathrm{R},-\mathrm{B}+\mathrm{R}$, and $+\mathrm{B}+\mathrm{R})$ were randomized among subplots. The entire experiment was repeated twice.

Each Cone-tainer received $15 \mathrm{ml}$ of sterile water at planting and then $10 \mathrm{ml}$ of sterile water each day until emergence of seedling. The sterile water then was replaced once every 3 days with $15 \mathrm{ml}$ of $50 \%$ Hoagland's solution containing $0.5 \mathrm{M} \mathrm{K}_{2} \mathrm{SO}_{4}, 1 \mathrm{M}$
$\mathrm{MgSO}_{4}, 0.05 \mathrm{M} \mathrm{Ca}_{2}\left(\mathrm{H}_{2} \mathrm{PO}_{4}\right), 0.01 \mathrm{M} \mathrm{CaSO}_{4}, \mathrm{FeEDTA}$ at $0.134 \mathrm{~g} /$ $100 \mathrm{ml}$, and micronutrient solution at $1 \mathrm{ml} /$ liter consisting of $2.86 \mathrm{~g}$ of $\mathrm{H}_{3} \mathrm{BO}_{3}, 1.81 \mathrm{~g}$ of $\mathrm{MnCl}_{2} \cdot 4 \mathrm{H}_{2} \mathrm{O}, 0.22 \mathrm{~g}$ of $\mathrm{ZnSO}_{4} \cdot 7 \mathrm{H}_{2} \mathrm{O}$, $0.08 \mathrm{~g}$ of $\mathrm{CuSO}_{4} \cdot 5 \mathrm{H}_{2} \mathrm{O}$, and $0.02 \mathrm{~g}$ of $\mathrm{H}_{2} \mathrm{MoO}_{4} \cdot \mathrm{H}_{2} \mathrm{O}$ in 1 liter of $\mathrm{H}_{2} \mathrm{O}$. Plants were grown in growth cabinets maintained at 23 and $20^{\circ} \mathrm{C}$ day and night, respectively, with $80 \%$ relative humidity. Lighting was maintained for $16 \mathrm{~h} /$ day generating a photon flux of $210 \mu \mathrm{mol} \mathrm{m}^{-2-1}$ (PAR) at the surface of the Cone-tainer.

Evaluation of disease. At harvesting (1 and 2 weeks after seeding), the plants were removed from the Cone-tainers and the root system was washed with tap water. The severity of hypocotyl rot caused by $R$. solani was evaluated visually for each plant using a disease severity scale ranging from 0 to 5 on the basis of necrotic lesion development (4), where $0=$ no lesions on hypocotyls, $1=$ lesions $\leq 2.5 \mathrm{~mm}$ long, $2=$ lesions 2.5 to $5.0 \mathrm{~mm}$ long, $3=$ lesions $\geq 5.0 \mathrm{~mm}$ long, $4=$ lesions girdling the seedling, and $5=$ seedling is damped-off. Disease severity in each replicate was determined by averaging the sum of individual scores of two seedlings per Cone-tainer.

Primer design. All primers used in this study (Table 1) were designed using the software DNAman (version 4.13) based on bean mRNA sequences deposited in GenBank. The specificity of the primers was checked by alignments with the original GenBank sequences using the standard nucleotide-nucleotide BLAST (blastn; provided online by NCBI). Because each primer set is located on the same exon of the gene, they can amplify genomic DNA as well as cDNA. Therefore, DNase treatment was carried out to ensure that RNA samples were DNA free. Conventional RT-PCR and PCR assays followed by gel electrophoresis were performed to verify the amplification of bean cDNA and genomic DNA using the designed primers. Melting point analysis was performed at the end of the real-time RT-PCR to confirm the amplification of a unique product for each gene (Fig. 1A).

RNA extraction and RT. After scoring the plants (at 1 and 2 weeks old) for disease severity, the plants were separated into roots, stems, and leaves and flash-frozen with liquid nitrogen and stored at $-80^{\circ} \mathrm{C}$. The entire explant tissue of each treatment was ground into fine powder in liquid nitrogen using a mortar and pestle. Total RNA from 1- and 2-week-old plants was extracted from $100 \mathrm{mg}$ of ground tissue using the RNeasy Plant Mini Kit (Qiagen Inc., Mississauga, ON, Canada) and DNase treated by the RNase-Free DNase Set (Qiagen), according to the manufacturer's recommendations. Contamination of residual genomic DNA in all RNA samples was verified by conventional PCR amplification on total RNA using the designed primers listed in Table 1. RNA samples containing DNA were further DNase treated until no PCR amplification of RNA samples was obtained. Prior to retrotranscription experiments, the concentration and integrity of RNA were verified by an optical density at $260 \mathrm{~nm}\left(\mathrm{OD}_{260}\right) / \mathrm{OD}_{280}$ absorption ratio using Beckman DU640 spectrophotometer and electrophoresis on formaldehyde agarose gel according to the manufacturer's recommendations. Total RNA was quantified

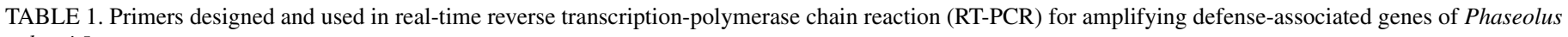
vulgaris $^{\mathrm{z}}$

\begin{tabular}{|c|c|c|c|c|c|}
\hline Target gene & Primer name & Primer sequence $\left(5^{\prime}-3^{\prime}\right)$ & $\begin{array}{l}\text { PCR product } \\
\text { size (bp) }\end{array}$ & $\begin{array}{l}\text { Gene location } \\
\text { (accession no.) }\end{array}$ & Reference \\
\hline \multirow[t]{2}{*}{$p G 101$} & PvglucF & GCTGTAAGGGCTCAAGGCCTC & 427 & $357-783(X 53129)$ & 9 \\
\hline & PvglucR & CCAAGTACACACGTGCGTTGTC & $\ldots$ & $\ldots$ & $\ldots$ \\
\hline \multirow[t]{2}{*}{$g P A L 1$} & PvpalF & AAGCCATGTCCAAAGTGCTG & 240 & 798-1037 (M11939) & 6 \\
\hline & PvpalR & GAGTTCTCCGTTGCCACCT & $\ldots$ & $\ldots$ & $\ldots$ \\
\hline \multirow[t]{2}{*}{ CHS17 } & PvchsF & CAAACTCTTGGGACTTCGGC & 180 & 492-671 (X06411) & 35 \\
\hline & PvchsR & CTGGGTGTCACTTGGCCC & $\ldots$ & 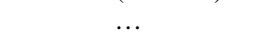 & $\ldots$ \\
\hline \multirow[t]{2}{*}{ Actin homolog } & PvactinF & CACCGAGGCACCGCTTAATC & 126 & $177-302(\mathrm{AB} 067722)$ & $\begin{array}{c}\text { (K. Takahara, S. Hamada, } \\
\text { H. Matsui, and H. Ito, } \\
\text { unpublished data) }\end{array}$ \\
\hline & PvactinR & CGGCCACTAGCGTAAAGGGAA & $\ldots$ & $\ldots$ & $\ldots$ \\
\hline
\end{tabular}

${ }^{\mathrm{z}} p G 101=1,3-\beta$-D-glucanase; $g P A L 1=$ phenylalanine ammonia lyase CHS17 = chalcone synthase; and actin homolog. 

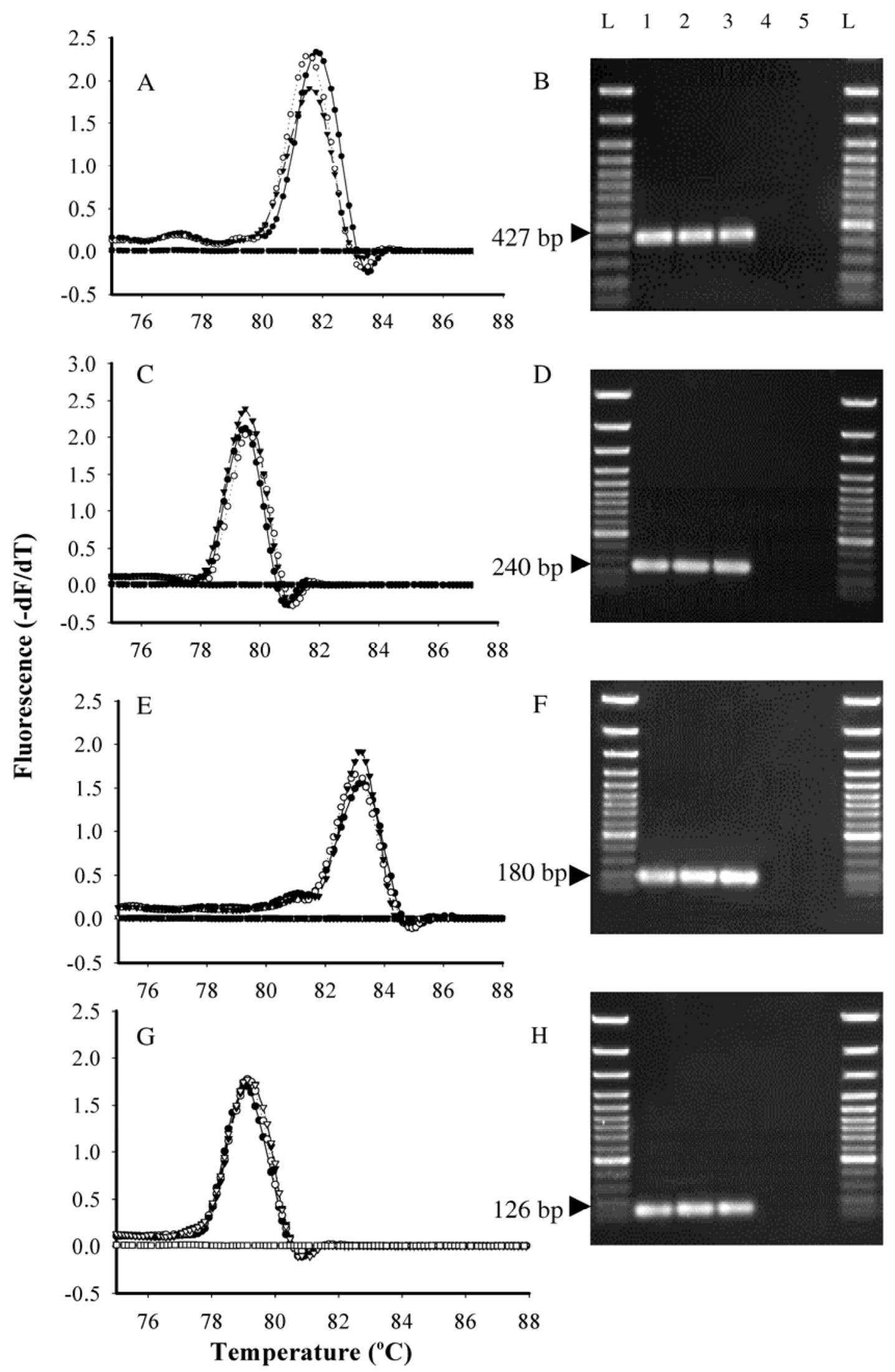

Fig. 1. Example of analysis of specificity of real-time quantitative reverse transcription-polymerase chain reaction products amplified for the following defenseassociated genes: $\mathbf{A}$ and $\mathbf{B}, p G 101 ; \mathbf{C}$ and $\mathbf{D}, g P A L 1 ; \mathbf{E}$ and $\mathbf{F}, C H S 17$; and $\mathbf{G}$ and $\mathbf{H}$, actin, using the designed primers listed in Table 1. A, C, E, and G, Melting peak profiles. A, $p G 101$ transcripts; C, $g P A L 1$ transcripts; D, $C H S 17$ transcripts; E, actin transcripts. Symbols: $\bullet=$ cDNA from leaves, $\bigcirc=$ cDNA from stems, $\boldsymbol{\nabla}=$ cDNA from roots, $\nabla=$ negative control, and $\mathbf{~ = ~ R N A ~ s a m p l e . ~ B , ~ D , ~ F , ~ a n d ~ H , ~ C o r r e s p o n d i n g ~ a g a r o s e ~ g e l ~ ( 1 . 0 \% ) ~ e l e c t r o p h o r e s i s . ~ L a n e s : ~ L ~ = ~ 1 0 0 - b p ~ D N A ~}$ ladder; lanes 1 to $3=$ amplification of cDNA from $62.5 \mathrm{pg}$ of RNA of bean leaves, stems, and roots respectively; lane $4=$ negative control; and lane $5=$ amplification of $17 \mathrm{ng}$ of bean RNA template. 
assuming that $\mathrm{OD}_{260}$ of 1.0 approximates RNA at $40 \mu \mathrm{g} / \mathrm{ml}$. An amount of $0.5 \mu \mathrm{g}$ of total RNA was reverse transcribed into $20 \mu \mathrm{l}$ of cDNA using the QIAGEN Omniscript RT Kit according to the manufacturer's recommendation.

cDNA amplification of defense-associated genes by conventional RT-PCR. Conventional RT-PCR assays were performed on cDNA templates, prepared from total RNA that was extracted from bean tissues, using the designed primers listed in Table 1. cDNA samples were diluted 100-fold with autoclaved Elga pure water in order to minimize the suppression of PCR by RT solution; whereas, with diluted samples showing low amplification, original concentrations were used. Amplification was performed in a $25-\mu \mathrm{l}$ reaction mixture containing $2.5 \mu \mathrm{l}$ of $10 \times$ PCR buffer, $2.5 \mu \mathrm{l}$ of $8 \mathrm{mM}$ (2 mM each) dNTP, $2.5 \mu \mathrm{l}$ of $15 \mathrm{mM} \mathrm{MgCl}_{2}$, $2.5 \mu \mathrm{l}$ of $2 \mu \mathrm{M}$ of each primer, $10.4 \mu \mathrm{l}$ of PCR water, $0.1 \mu \mathrm{l}$ of $5 \mu / \mu \mathrm{l} \mathrm{Taq}$ polymerase (Invitrogen Life Technologies, Burlington, ON, Canada), and $2 \mu \mathrm{l}$ of cDNA. The amplification conditions for pG101 cDNA were $94^{\circ} \mathrm{C}$ for 3 min for denaturing, followed by 30 cycles of amplification at $94^{\circ} \mathrm{C}$ for $1 \mathrm{~min}, 65^{\circ} \mathrm{C}$ for $1 \mathrm{~min}$, and $72^{\circ} \mathrm{C}$ for 2 min. Following amplification, a 10-min extension at $72^{\circ} \mathrm{C}$ was added at the end of the run. The amplification conditions for $g P A L 1, C H S 17$, and the internal control gene, actin, were as follows: $94^{\circ} \mathrm{C}$ for $2 \mathrm{~min}$, followed by 30 cycles amplification at $94^{\circ} \mathrm{C}$ for $1 \mathrm{~min}, 64^{\circ} \mathrm{C}$ for $1 \mathrm{~min}$, and $72^{\circ} \mathrm{C}$ for $2 \mathrm{~min}$. An extension step similar to that for $p G 101$ was performed at the end the run. In all RT-PCR runs, appropriate negative controls containing no cDNA template were subjected to the same procedure in order to exclude or detect possible contamination or carryover.

The RT-PCR products for all target genes were purified using QIAquick PCR Purification Kit and quantified using Beckman DU640 spectrophotometer. Depending on the gene, serial dilutions of purified RT-PCR products in the range of concentration from $10^{1}$ to $10^{9}$ copies and over 4 to 5 orders of magnitude were prepared to generate standard curves for real-time QRT-PCR assays.

Gene expression analysis by real-time QRT-PCR. Real-time QRT-PCR was performed for each of the defense-associated genes and for actin on cDNA templates prepared from total RNA that was extracted from bean tissues using the LightCycler (Roche, Montreal, QC, Canada) and SYBR Green PCR master mix (Qiagen) according to the manufacturer's recommendations (Qiagen). A set of standard solutions prepared from RT-PCR products was included in each run. Reactions were prepared in capillaries using the following concentrations: $10 \mu \mathrm{l}$ of SYBR Green master mix, $5 \mu \mathrm{l}$ of PCR water, $2 \mu \mathrm{l}$ of each primer set (Table 1), and $1 \mu$ of cDNA or standard solution as template. The amplification conditions for $p G 101 \mathrm{cDNA}$ were $95^{\circ} \mathrm{C}$ for $15 \mathrm{~min}$ to activate the hot-start recombinant Taq DNA polymerase, followed by 55 cycles of amplification at $94^{\circ} \mathrm{C}$ for $15 \mathrm{~s}, 65^{\circ} \mathrm{C}$ for $20 \mathrm{~s}$, $72^{\circ} \mathrm{C}$ for $35 \mathrm{~s}$, and $79^{\circ} \mathrm{C}$ for $5 \mathrm{~s}$ to avoid dimer formation. Following amplification, a melting curve program $\left(70\right.$ to $95^{\circ} \mathrm{C}$ with a

TABLE 2. Effect of nonpathogenic binucelate Rhizoctonia spp. (np-BNR) inoculation on disease severity caused by Rhizoctonia solani

\begin{tabular}{|c|c|c|}
\hline \multirow[b]{2}{*}{ Treatment description and designation } & \multicolumn{2}{|c|}{ Disease scale ${ }^{z}$} \\
\hline & Week 1 & Week 2 \\
\hline Mock inoculated (-B-R) & $0 \mathrm{c}$ & $0 \mathrm{c}$ \\
\hline Plants inoculated with np-BNR 232-CG only (+B-R) & $0 \mathrm{c}$ & $0 \mathrm{c}$ \\
\hline Plants infected with $R$. solani only $(-\mathrm{B}+\mathrm{R})$ & $5 \mathrm{a}$ & $5 \mathrm{a}$ \\
\hline $\begin{array}{l}\text { Plants inoculated with np-BNR 232-CG and } \\
\text { infected with } R \text {. solani }(+\mathrm{B}+\mathrm{R})\end{array}$ & $2 \mathrm{~b}$ & $2 \mathrm{~b}$ \\
\hline \multicolumn{3}{|c|}{$\begin{array}{l}\text { Disease severity scale for } R \text {. solani ranged from } 0=\text { no lesions on } \\
\text { hypocotyls, } 1=\text { lesions } \leq 2.5 \mathrm{~mm} \text { long, } 2=\text { lesions } 2.5 \text { to } 5.0 \mathrm{~mm} \text { long, } 3= \\
\text { lesions } \geq 5.0 \mathrm{~mm} \text { long, } 4=\text { lesions girdling plant, and } 5=\text { plant damped-off. } \\
\text { Values represent median of six replicates. Values in a column with different } \\
\text { letters are significantly different }(P<0.05) \text { (Mann-Whitney tests). }\end{array}$} \\
\hline
\end{tabular}

heating rate of $0.1{ }^{\circ} \mathrm{C} / \mathrm{s}$ ) and finally a cooling step to $40^{\circ} \mathrm{C}$ were added. The amplification conditions for $g P A L 1, C H S 17$, and actin cDNA were as follows: $95^{\circ} \mathrm{C}$ for $25 \mathrm{~min}$, followed by 45 cycles amplification at $94^{\circ} \mathrm{C}$ for $15 \mathrm{~s}, 64^{\circ} \mathrm{C}$ for $20 \mathrm{~s}$, and $72^{\circ} \mathrm{C}$ for $6 \mathrm{~s}$. Similar conditions for melting curve and cooling step as those for pG101 were conducted.

The Fit Points Method was performed using the LightCycler software 3.3 for the analysis of the standard curve. The crossing points (CPs) were determined at a fixed fluorescence threshold of 0.2 . A linear relationship was obtained for each run by plotting the threshold cycle numbers (CTs) against the logarithm of cDNA copies of a set of standard solutions. The equation of the line that best fits the data was determined by minimizing error for regression analysis. The $R^{2}$ value was calculated to estimate the accuracy of the real-time RT-PCR as a quantification method. The slope of the standard curve was used to calculate the efficiency of the real-time QRT-PCR according to the formula $\mathrm{E}=10^{(-1 / \text { slope })}$. The fold changes of defense-associated gene transcripts in different treatments versus control (i.e., mock treatment) were normalized using the CT and efficiency obtained for the actin amplification run on the same cDNA templates using the formula established by Pfaffl (30) and modified by McMaugh and Lyon (28): fold change $=\left[\left(\mathrm{E}_{\mathrm{gene}}\right)^{\Delta \mathrm{Ct}}{ }_{\text {gene }}{ }^{(\text {control - sample })}\right] /\left[\left(\mathrm{E}_{\mathrm{actin}}\right)^{\Delta \mathrm{Ct}}{ }_{\text {actin }}{ }^{\text {(control - sample })}\right]$, where $\mathrm{E}_{\text {gene }}$ is the real-time RT-PCR efficiency of a defense gene transcript, $E_{\text {actin }}$ is the real-time RT-PCR efficiency of the housekeeping gene actin transcript, $\Delta \mathrm{CT}_{\text {gene }}$ is the $\mathrm{CT}$ deviation of control - sample of the target gene transcripts, and $\Delta \mathrm{CT}_{\text {actin }}=\mathrm{CT}$ deviation of control - treatment of actin transcripts.

Statistics. Disease severity scores were subjected to the KurskalWallis test, a nonparametric ranking procedure, using PROC NPAR1WAY in SAS (36). Because the overall Kruskal-Wallis test was significant $(P<0.0001)$, pairwise comparisons of treatments were done using Mann-Whitney tests. The fold changes of defense-associated gene transcripts were tested for significant difference between harvesting time (1- and 2-week-old) and inoculation treatments using two-way analysis of variance (ANOVA). The data generated from repeated trials were tested for homogeneity using the $\chi^{2}$ test (12). Where appropriate, the data were pooled and analyzed as six blocks. Data were tested for normality and were transformed using $\log X+1$ wherever necessary. Statistical analyses of fold change of defense gene transcripts were done using PROC GLM in SAS (36). Comparisons between means were made using least significant differences at a 0.05 probability when ANOVA indicated model and treatment significances.

\section{RESULTS}

Effect of np-BNR on stem rot of bean. Bean seedlings inoculated with np-BNR $(+B-R)$ like mock-inoculated plants $(-\mathrm{B}-\mathrm{R})$ showed no symptoms regardless of the harvesting period (Table 2). Seedlings protected with isolate 232-CG and infected with $R$. solani $(+\mathrm{B}+\mathrm{R})$ had significantly $(P<0.05)$ lower disease severity compared with those that were infected with $R$. solani but nonprotected $(-\mathrm{B}+\mathrm{R})$.

Quantification of defense-associated gene transcripts in bean. The choice of the defense-associated genes studied was dictated by the fact that all of them have been reported to be activated in bean tissues upon elicitation, wounding, or infection (Table 1). Each primer set, designed to amplify a particular defense gene or the housekeeping gene actin, had successfully amplified a unique putative product of similar size when cDNA (Fig. 1B, D, F, and H) and DNA (data not shown) were used as template in conventional RT-PCR runs. However, before initiating real-time QRT-PCR experiments, all total plant RNA samples were treated with RNase-free DNase prior to reverse transcription and tested for the presence of DNA by PCR amplification assays using the designed primer pairs. No signal or PCR products were 
detected when RNA was used as template (Fig. 1B, D, F, and H). A LightCycler melting curve analysis was performed for specificity of quantitative RT-PCR products for each primer set which resulted in single products with the following specific melting temperature: $p G 101,81.87 \pm 0.84^{\circ} \mathrm{C} ; g P A L 1,79.49 \pm 0.58^{\circ} \mathrm{C}$; CHS17, $82.83 \pm 1.33^{\circ} \mathrm{C}$; and actin, $79.74 \pm 1.18^{\circ} \mathrm{C}$ (Fig. $1 \mathrm{~A}, \mathrm{C}, \mathrm{E}$, and $\mathrm{G})$.

Standard curves and sensitivity of real-time QRT-PCR. In this study, standard curves for each of the four genes were constructed using different concentrations of amplified cDNA products that ranged over four- to fivefold magnitude. A linear regression relation between logarithm of known gene cDNA copy number and real-time CTs over the range of cDNA concentrations was established (Fig. 2). For all of the four genes studied, the square regression correlation coefficient $\left(R^{2}\right)$ of detection ranged between 0.9901 and 1.0000 (Fig. 2).

Depending on the gene, titers as low as $10^{1}$ of template molecules of target transcripts could be reproducibly detected using SYBR Green Dye1. Amplification plots were highly reproducible between triplicate samples of the same treatment (Fig. 3A to D), and fluorescence data from negative controls con- taining no templates always remained well below the threshold level.

Validation of reference gene for normalization. The amount of the housekeeping gene actin did not show significant change between treatments $(P>0.05)$ (Fig. 3D). Thus, the relative expression ratio of defense-associated genes in the treated plants versus the control $(-\mathrm{B}-\mathrm{R})$ was estimated by normalizing against actin (Fig. 4).

Spatial expression of defense-associated gene transcript levels. There were no significant differences $(P>0.05)$ in temporal expression of defense-related gene transcripts between the two harvesting times (i.e., 1 and 2 weeks). Therefore, we present the results only for the first harvesting time point. There was a systemic and spatial expression of transcript levels of $p G 101$, gPAL1, and CHS17 genes in bean seedlings that were either infected with $R$. solani, protected with np-BNR, or both; although, in general, transcript levels were lower in roots than in leaves and stems (Fig. 4). Compared with the mock treatment, the highest defense gene expression was achieved in $R$. solani-infected stems for CHS17 (41-fold) and pG101 (26-fold) (Fig. 4C and A), followed by $g P A L 1$ ( 8 -fold) in leaves of the same treatment (Fig.
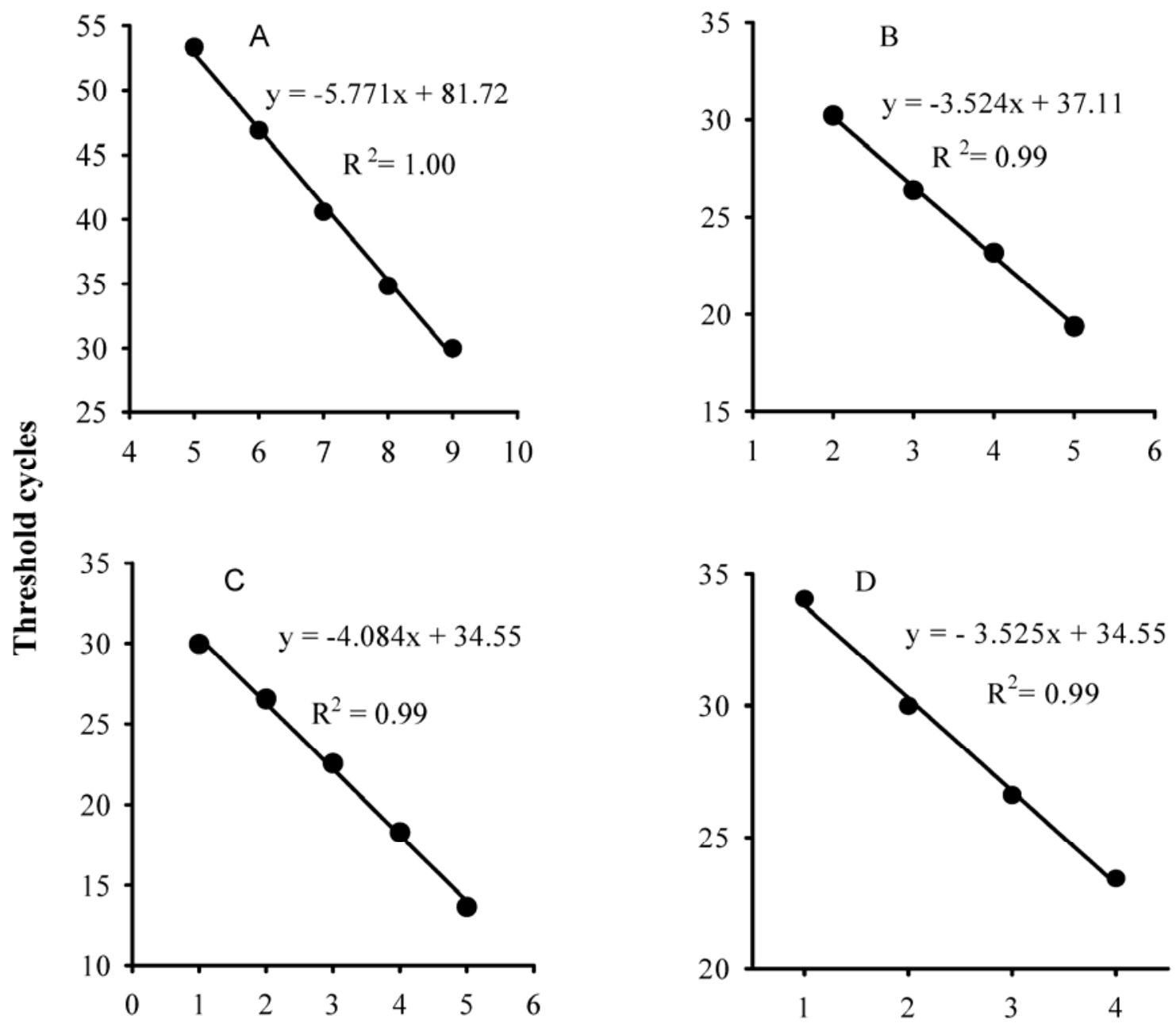

\section{$\log 10$ (cDNA copies)}

Fig. 2. Example of real-time quantitative reverse transcription-polymerase chain reaction (QRT-PCR) efficiencies for the defense-associated genes $p G 101, g P A L 1$, CHS17, and bean actin. Depending on the gene, purified RT-PCR products were diluted serially in the range of concentration from $10^{1}$ to $10^{9}$ copies and over four to five orders of magnitude to be amplified in QRT-PCR assay. The crossing points (CPs) were determined at a fixed fluorescence threshold of 0.2. A linear relationship was obtained for each run by plotting the threshold cycle number $(\mathrm{Ct})$ against the logarithm of the known copies of starting template in the dilution series. The equation of the line that best fits the data was determined by minimizing error for regression analysis. The $R^{2}$ value was calculated to estimate the accuracy of the real-time RT-PCR as a quantification method. The slope of the standard curve was used to calculate the efficiency of the real-time QRT-PCR according to the formula $\mathrm{E}=10^{(-1 / \text { slope })}$. A, $p G 101 ; \mathbf{B}, g P A L 1 ; \mathbf{C}$, CHS17; and $\mathbf{D}$, actin homolog transcripts. 
4B). Protected and infected seedlings $(+B+R)$ showed a significant down-regulation $(P<0.05)$ of transcript levels in all tissues for $p G 101$ and in leaves and stems for $g P A L 1$ and $C H S 17$ genes compared with those that are infected and not protected $(-\mathrm{B}+\mathrm{R})$. This decrease ranged between two- and fourfold depending on the tissue and the gene analyzed (Fig. 4). Regardless of the tissue analyzed, transcript levels of $p G 101, g P A L 1$, and CHS17 in npBNR-protected and $R$. solani-infected $(+\mathrm{B}+\mathrm{R})$ bean seedlings were not significantly different from those estimated in protected but noninfected seedlings (+B-R). Of interest, the relative expression ratio of $g P A L 1$ and $C H S 17$ genes in protected but noninfected root tissue $(+\mathrm{B}-\mathrm{R})$ was $<1$, lower than the background expression value estimated in mock treatments (Fig. 4B and C).

\section{DISCUSSION}

Our results indicate that inoculation of bean seed at planting with $\mathrm{np}-\mathrm{BNR}$ isolate 232-CG significantly protected bean seedlings from infection with the pathogen $R$. solani. Similar protection by the same np-BNR isolate and by different isolates belonging to several anastomosis groups was achieved on potato (10), poinsettia (21), snap bean (4), cucumber $(7,43)$, corn (29), creeping bentgrass (2), cabbage (33), and several nursery plants (17). The protection efficiency of np-BNR isolates has been reported to vary, depending on the np-BNR isolate used $(10,43)$, inoculation time $(29,43)$, inoculum type (5), and environmental factors $(2,33)$. Pre-inoculation of plants with np-BNR isolates 1 to 3 days earlier to subsequent challenge with $R$. solani has been reported to be effective in controlling disease $(2,18,29)$. In this study, we have achieved $60 \%$ reduction in Rhizoctonia stem rot by simultaneous inoculation of bean plants with np-BNR 232-CG and $R$. solani at seeding. These results indicate that np-BNR 232$\mathrm{CG}$ played an important role in preventing the onset of the disease and in reducing the rate of disease expansion.

To the best of our knowledge, we are the first to perform realtime QRT-PCR assays to quantify the levels of spatial alteration of defense-related gene transcripts during interaction of bean plants with a nonpathogenic fungus in the presence of a pathogen. Several factors that may affect the reliability of real-time QRTPCR were carefully controlled in conducting our experiments. (i) Specific primer sets were designed that amplified unique single products that were confirmed by melting curve and gel analyses. Only the primers amplifying unique bands and revealing single melting peaks were chosen for use in this study. (ii) DNase treatment on all RNA samples was a must because the reference gene and all the defense genes used in this study contained only one exon, and the designed primers in this case could not avoid amplifying genomic DNA. (iii) Constructing linearity standard curves with coefficient correlations $\left(r^{2}\right)$ ranging from 0.99 to 1.00 led to accurate calculation of the amplification efficiency that was used in calculation of the relative level of gene transcripts. (iv) It was statistically validated that the expression levels of the housekeeping gene actin remained constant $(P>0.05)$ with treatment. This was essential because it has been reported that actin varies considerably and that it cannot be used reliably as an internal control $(15,37,40)$. (v) A proper mathematical model $(28,30)$ that accounts for both differences in amplification efficiency and threshold cycle numbers was chosen. The results obtained with
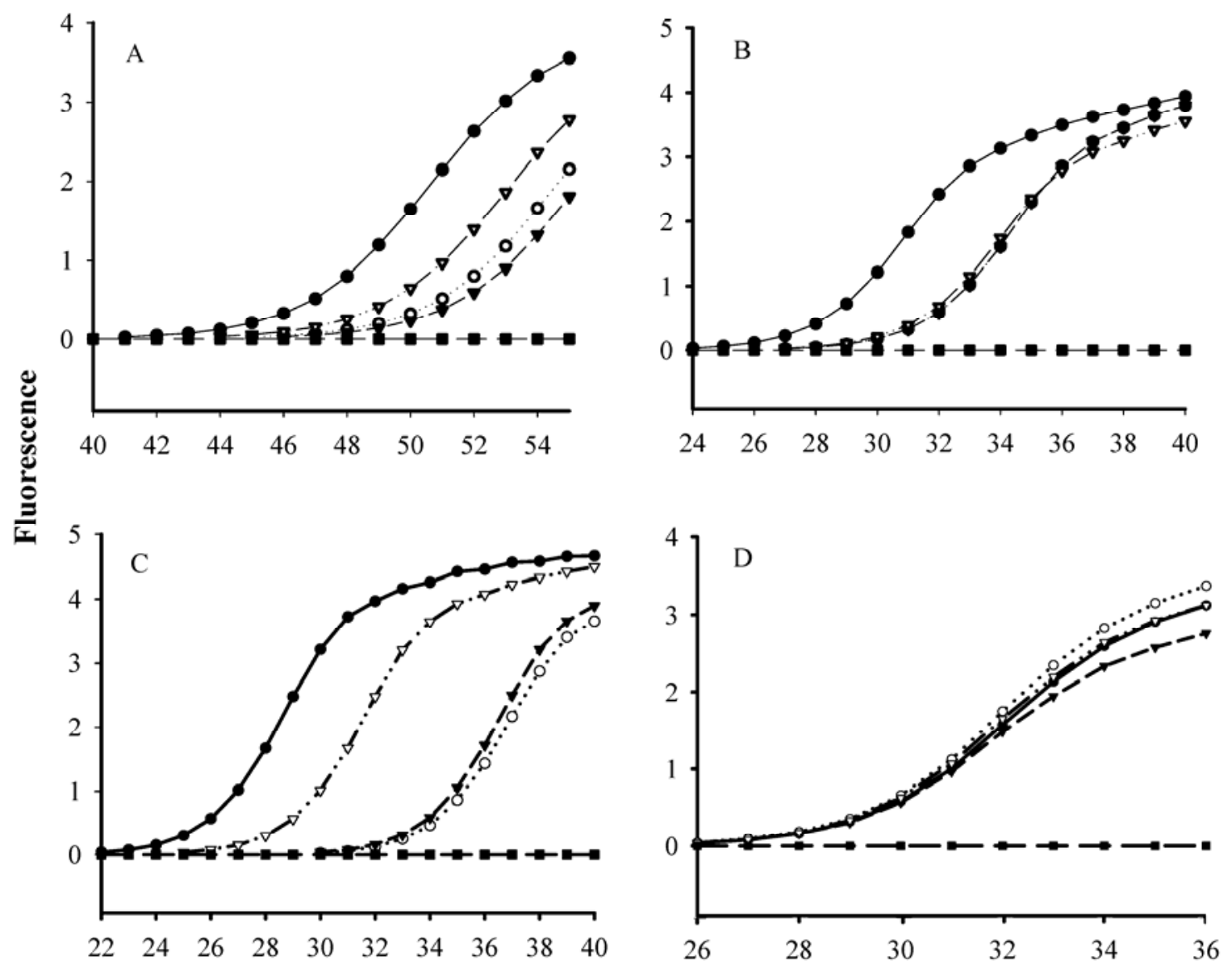

Cycle number

Fig. 3. Kinetics of fluorescence signal versus cycle numbers measured during amplification of the defense-associated genes $p G 101, g P A L 1$, CHS17, and the house-keeping gene bean actin cDNA subjected to four inoculation treatments. A, $p G 101$ cDNA transcripts; B, gPAL1 cDNA transcripts; C, CHS17 cDNA transcripts; and D, actin transcripts. Symbols: $\mathrm{O}=+\mathrm{B}-\mathrm{R}, \boldsymbol{Q}=-\mathrm{B}+\mathrm{R}, \nabla=+\mathrm{B}+\mathrm{R}, \boldsymbol{\nabla}=-\mathrm{B}-\mathrm{R}$, and $\boldsymbol{\boldsymbol { a }}=$ negative control. 
this formula were identical to those calculated by the Roche Light Cycler Relative quantification software (32).

The significant increase in the spatial expression of transcript levels of $p G 101, g P A L 1$, and $C H S 17$ in bean seedlings due to $R$. solani infection is a strong indication that $R$. solani stimulated a systemic accumulation of GLUC, a PR protein (27), and production of CHS and PAL, two key enzymes of the phenylpropanoid pathway that lead to phytoalexin accumulation $(6,35)$. In addition, the results of this study clearly showed that the expression of mRNA did not remain restricted to the vicinity of $R$. solani infection sites (crowns and hypocotyls), but spread rapidly to nonprotected and noninfected tissues (i.e., the cotyledons and leaves). This phenomenon implies, therefore, the existence of a signal that spreads systematically from the hypocotyls to the rest of the plant. Many studies have indicated that SA, a natural phenolic compound, is an important signaling factor in the induction of SAR $(23,24,34)$. In a previous histochemical study conducted by Jabaji-Hare et al. (22), $R$. solani successfully invaded the bean cortical tissue, causing cell wall degradation. It is very likely that cell wall fragments might have served as elicitors to produce a signal in infected plants, such as SA leading to substantially higher expression levels of the defense gene encoding GLUC, PAL, and CHS.

Of interest, inoculation of bean seed with np-BNR $(+B-R)$ did not elicit a significant defense response as demonstrated by levels of gene expression similar to that of the noninoculated control. However, the presence of np-BNR significantly affected the plant's defense responses only during a pathogenic infection $(+\mathrm{B}+\mathrm{R})$ by significantly down-regulating the expression of the defense genes at the mRNA levels relative to those estimated in infected seedlings $(-\mathrm{B}+\mathrm{R})$. These findings indicate that protection of bean seedlings with np-BNR against $R$. solani is not the result of the activation of $p G 101, g P A L 1$, and $C H S 17$ genes 1 or 2 weeks after inoculation. Instead, protection could be associated with a stronger cell wall fortification resulting from the activation of defense genes encoding structural proteins such as HRGP (11) or the deposition of phenols, suberin, and pectic substances in npBNR-protected epidermal and cortical cells. This ultimately would strengthen and alter the host's cell wall, providing a barrier for the invading hyphae of $R$. solani (22). Alternatively, the downregulation also could be viewed as a weaker elicitation because of a lower development of the pathogen in protected plants that may be mediated by any other possible mechanism involved in disease suppression.

Another plausible possibility is that the activation of the plant's defense response occurred earlier than 1 week. We previously have provided evidence that substantial increases in enzymatic activities of peroxidases and PR proteins (46), as well as in total mRNA transcripts encoding PR proteins and PAL (45) in etiolated bean seedlings $48 \mathrm{~h}$ after inoculation with np-BNR, were associated with reduction in disease severity caused by $R$. solani. The discrepancy in the results of these studies could be explained by the fact that np-BNR stimulated an earlier (hours after inoculation) but transient systemic activation of some defense genes during the establishment of np-BNR colonization on bean plants (earlier studies) followed by down-regulation at later stages (this study). The early but transient activation of defense genes may have been sufficient to provide bean plants protection against R. solani.

Down-regulation or suppression of the plant's defense encoding genes in response to other nonpathogenic interactions is not a new phenomenon. During the arbuscular mycorrhizal (AM) symbiotic interaction, the expression of $M D 17$, a cDNA encoding a basic chitinase, was suppressed during the establishment and colonization of the AM fungus Glomus intraradices in tobacco roots (8); whereas, during dual inoculation of bean and alfalfa with $G$. intraradices and $R$. solani, mRNA transcripts encoding key enzymes in the phenylpropanoid pathway $(13,14)$ or encoding glucanases (44) were down-regulated to levels below those observed in infected plant tissues. Taken together, the results of the current study along with previous studies clearly strengthen the concept that plants suppress or down-regulate the defense response elicited by pathogenic fungi during root and stem colonization by AM fungi and np-BNR, respectively. Further research is needed to understand the mechanism implicated in down-regulation during plant-pathogen-np-BNR interaction. In AM-plantpathogen interactions, it has been proposed that suppressor molecules originating from AM fungi can suppress the plant's defense response for facilitating establishment of AM colonization, and this suppression overcomes pathogen elicitation (13). Whether similar suppressor molecules exist during np-BNR colonization and can overcome the pathogen elicitation needs to be further investigated.

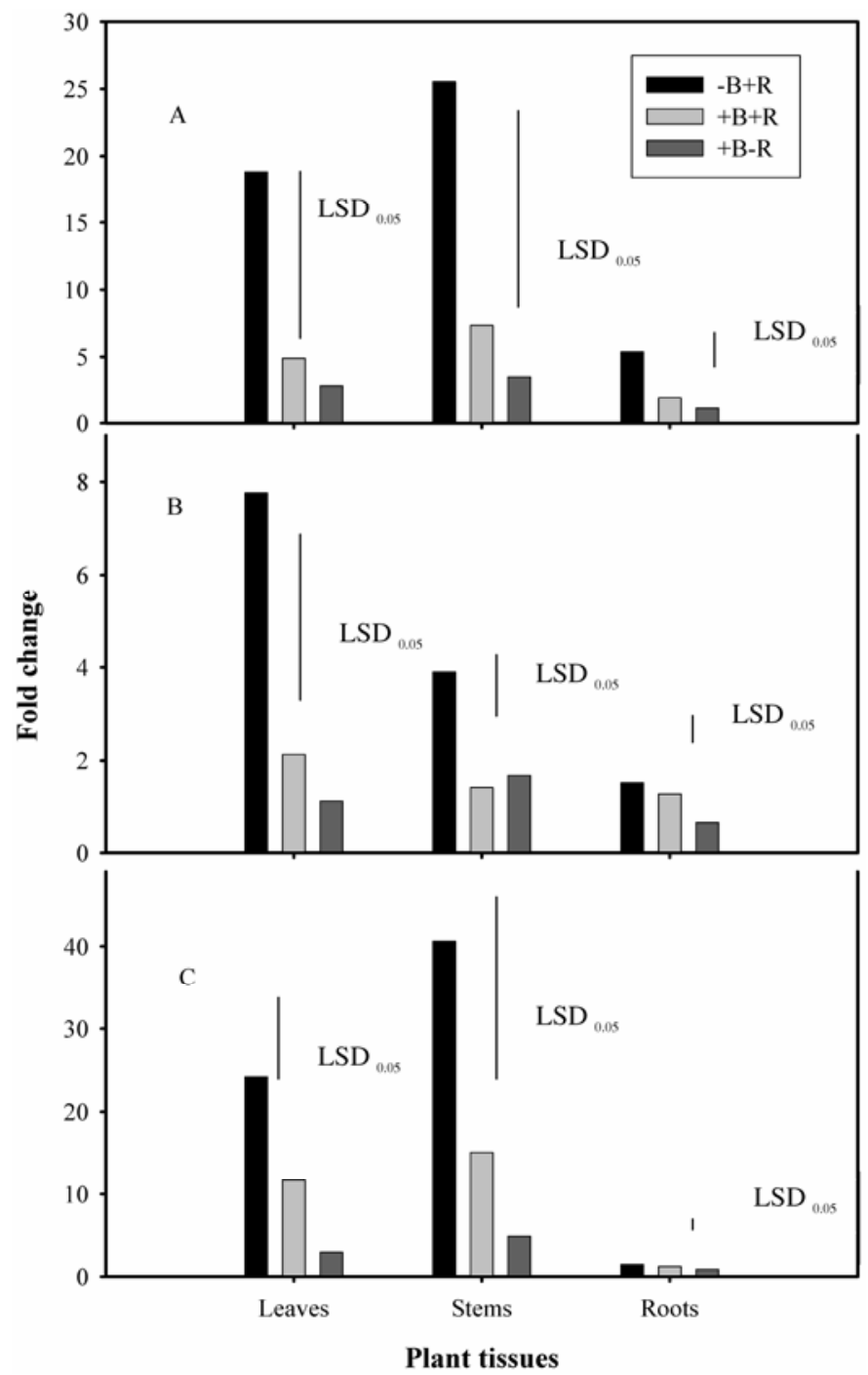

Fig. 4. Effect of inoculation with nonpathogenic binucleate Rhizoctonia spp. (np-BNR) and infection with Rhizoctonia solani on transcript levels of the defense-associated genes A, pG101, B, gPAL1, and C, CHS17. Transcript levels were estimated using real-time quantitative reverse transcriptionpolymerase chain reaction (QRT-PCR). The crossing points were determined at a fixed fluorescence threshold of 0.2 . Fold change was calculated from the real-time QRT-PCR efficiencies and the threshold cycle $(\mathrm{Ct})$ deviation of an inoculation treatment versus control. The fold change represents the means of three replicates. Significance was determined among treatments using least significant difference $(\mathrm{LSD})(P<0.05) .+\mathrm{B}-\mathrm{R}=$ plants inoculated with np-BNR only; $-\mathrm{B}+\mathrm{R}=$ plants infected with $R$. solani only, and $+\mathrm{B}+\mathrm{R}=$ plants inoculated with $\mathrm{np}-\mathrm{BNR}$ and infected with $R$. solani. The fold change ratio of control (-B-R) was always 1 and was not included in the statistical analyses. 
In summary, the present study provides evidence that QRT-PCR is a powerful technique in quantification of defense-associated genes transcript levels, especially with low transcript levels. Inoculation of bean seed at sowing with a nonpathogenic isolate of binucleate Rhizoctonia sp. (np-BNR) reduced disease symptoms caused by $R$. solani. However, this protection seems to be unrelated to $p G 101, g P L A 1$, and $C H S 17$ activation elicited by npBNR. For better understanding of the mechanisms responsible for bioprotection of nonpathogenic fungi, analysis of several defenseassociated genes, earlier sampling times (hours after inoculation), characterizing signals, and study of competition for infection sites need to be further investigated.

\section{ACKNOWLEDGMENTS}

This work was supported by a research grant from the Fond pour la Formation des Chercheurs et l'Aide a la Recherche (FCAR-IRDA) grant to S. H. Jabaji-Hare (leader), C. Hamel, M. St-Arnaud, and R. Hogue; and partly by an Natural Sciences and Engineering Research Council of Canada (NSERC) grant to S. H. Jabaji-Hare. We thank G. Taylor for his technical help.

\section{LITERATURE CITED}

1. Benitez-Burraco, A., Balnco-Portales, R., Redondo-Nevado, J., Bellido, M. L., Moyano, E., Caballero, J.-L., and Munoz-Blanco, J. 2003. Cloning and characterization of two ripening-related strawberry (Fragaria $\times$ ananassa cv. Chandler) pectate lyase genes. J. Exp. Bot. 54:633-645.

2. Burpee, L. L., and Goulty, L. G. 1984. Suppression of brown patch disease of creeping bentgrass by isolates of nonpathogenic Rhizoctonia spp. Phytopathology 74:692-694.

3. Bustin, S. A. 2002. Quantification of mRNA using real-time reverse transcription PCR (RT-PCR): Trends and problems. J. Mol. Endocrinol. 29:23-39.

4. Cardoso, J. E., and Echandi, E. 1987. Biological control of Rhizoctonia root rot of snap bean with binucleate Rhizoctonia-like fungi. Plant Dis. 71:167-170.

5. Cartwright, D. K., and Spurr, H. W., Jr. 1998. Biological control of Phytophthora parasitica var. nicotianae on tobacco seedlings with nonpathogenic binucleate Rhizoctonia fungi. Soil Biol. Biochem. 30:18791884.

6. Cramer, C. L., Edwards, K., Dron, M., Liang, X., Dildine, S. L., Bolwell, G. P., Dixon, R. A., Lamb, C. J., and Schuch, W. 1989. Phenylalanine ammonia-lyase gene organization and structure. Plant Mol. Biol. 12:367383.

7. Cubeta, M. A., and Echandi, E. 1991. Biological control of Rhizoctonia and Pythium damping-off of cucumber: An integrated approach. Biol. Control 1:227-236.

8. David, R., Itzhaki, H., Ginzberg, I., Gafni, Y., Galili, G., and Kapulnik, Y. 1998. Suppression of tobacco basic chitinase gene expression in response to colinization by the arbuscular mycorrhizal fungus Glomus intraradices. Mol. Plant-Microbe Interact. 11:489-497.

9. Edgington, B. V., Lamb, C. J., and Dixon, R. A. 1991. cDNA cloning and characterization of a putative 1,3-beta-glucanase transcript induced by fungal elicitor in bean cell suspension cultures. Plant Mol. Biol. 16:8194.

10. Escande, A. R., and Echandi, E. 1991. Protection of potato from Rhizoctonia canker with binucleate Rhizoctonia fungi. Plant Pathol. 40:197-202.

11. Garcia-Muniz, N., Martinez-Izquierdo, J. A., and Puigdomenech, P. 1998. Induction of mRNA accumulation corresponding to a gene encoding a cell wall hydroxyproline-rich glycoprotein by fungal elicitors. Plant Mol. Biol. 1:623-632.

12. Gomez, K. A., and Gomez. A. A. 1984. Pages 467-471 in: Statistical Procedures for Agricultural Research. 2nd ed. John Wiley and Sons, New York.

13. Guenoune, D., Galili, S., Phillips, D. A., Volpin, H., Chet, I., Okon, Y., and Kapulnik, Y. 2001. The defense response elicited by the pathogen Rhizoctonia solani is suppressed by colonization of the AM-fungus Glomus intraradices. Plant Sci. 160:925-932.

14. Guillon, C., St.-Arnaud, M., Hamel, C., and Jabaji-Hare, S. H. 2002. Differential and systemic alteration of defense-related gene transcript levels in mycorrhizal bean plants infected with Rhizoctonia solani. Can. J. Bot. 80:305-315

15. Hamalainen, H. K., Tubman, J. C., Vikman, S., Kyrola, T., Ylikoski, E., Warrington, J. A., and Lahesmaa, R. 2001. Identification and validation of endogenous reference genes for expression profiling of $\mathrm{T}$ helper cell differentiation by quantitative real-time RT-PCR. Anal. Biochem. 299: 63-70.

16. Hammerschmidt, R. 1999. Phytoalexins: What have learned after 60 years. Annu. Rev. Phytopathol. 37:285-306.

17. Harris, A. R., and Adkins, P. G. 1999. Versatility of fungal and bacterial isolates for biological control of damping-off disease caused by Rhizoctonia solani and Pythium spp. Biol. Control 15:10-18.

18. Harris, A. R., Schisler, D. A., Neate, S. M., and Ryder, M. H. 1994. Suppression of damping-off caused by Rhizoctonia solani, and growth promotion, in bedding plants by binucleate Rhizoctonia spp. Soil Biol. Biochem. 26:263-268.

19. Heil, M., and Bostock, R. M. 2002. Induced systemic resistance (ISR) against pathogens in the context of induced plant defenses. Ann. Bot. 89:503-512.

20. Herr, L. J. 1995. Biological control of Rhizoctonia solani by binucleate Rhizoctonia spp. and hypovirulent $R$. solani agents. Crop Prot. 14:179186.

21. Hwang, J., and Benson, D. M. 2003. Expression of induced systemic resistance in poinsettia cuttings against Rhizoctonia stem rot by treatment of stock plants with binucleate Rhizoctonia. Biol. Control 27:73-80.

22. Jabaji-Hare, S., Chamberland, H., and Charest, P. M. 1999. Cell wall alterations in hypocotyls of bean seedlings protected from Rhizoctonia stem canker by a binucleate Rhizoctonia isolate. Mycol. Res. 103:10351043.

23. Kiefer, I. W., and Slusarenko, A. J. 2003. The pattern of systemic acquired resistance induction within the Arabidopsis rosette in relation to the pattern of translocation. Plant Physiol. 132:840-847.

24. Klessig, D. F., and Malamy, J. 1994. The salicylic acid signal in plants. Plant Mol. Biol. 26:1439-1458.

25. Lekanne-Deprez, R. H., Fijnvandraat, A. C., Ruijter, J. M., and Moorman, A. F. M. 2002. Sensitivity and accuracy of quantitative real-time polymerase chain reaction using SYBR green $\mathrm{O}$ depends on cDNA synthesis conditions. Anal. Biochem. 307:63-69.

26. Maguire, T. L., Grimmond, S., Forrest, A., Iturbe-Ormaetex, I., Maksem, K., and Gresshoff, P. 2002. Tissue-specific gene expression in soybean (Glycine max) detected by cDNA microarray analysis. J. Plant Physiol. 159:1361-1374.

27. Mauch, F., and Staeheline, L. A. 1989. Functional implications of the subcellular localization of ethylene-induced chitinase and 1,3-glucanase in bean leaves. Plant Cell 1:447-457.

28. McMaugh, S. J., and Lyon, B. R. 2003. Real-time quantitative RT-PCR assay of gene expression in plant roots during fungal pathogenesis. Biotechniques 34:982-986.

29. Pascual, C. B., Raymundo, A. D., and Hayakumachi, M. 2000. Efficacy of hypovirulent binucleate Rhizoctonia sp. to control banded leaf and sheath blight in corn. J. Gen. Plant Pathol. 66:95-102.

30. Pfaffl, M. W. 2001. A new mathematical model for relative quantification in real-time RT-PCR. Nucleic Acids Res. 29:2002-2007.

31. Poromarto, S. H., Nelson, B. D., and Freeman, T. P. 1998. Association of binucleate Rhizoctonia with soybean and mechanism of biocontrol of Rhizoctonia solani. Phytopathology 88:1056-1067.

32. Roche Diagnostics. 2001. Relative quantification. Pages 11-28 in: Roche Applied Science Technical Note. No. LC13/200, Basel, Switzerland.

33. Ross, R. E., Keinath, A. P., and Cubeta, M. A. 1998. Biological control of wirestem on cabbage using binucleate Rhizoctonia spp. Crop Prot. 17:99104.

34. Ryals, J., Uknes, S., and Ward, E. 1994. Systemic acquired resistance. Plant Physiol. 104:1109-1112.

35. Ryder, T. B., Hedrick, S. A., Bell, J. N., Liang, X., Clouse, S. D., and Lamb, C. J. 1987. Organization and differential activation of a gene family encoding the plant defense enzyme chalcone synthase in Phaseolus vulgaris. Mol. Gen. Genetics. 210:219-233.

36. SAS Institute. 1999. SAS 8. Software. SAS Institute, Cary, NC.

37. Schmittgen, T. D., and Zakrajsek, B. A. 2000. Effect of experimental treatment on housekeeping gene expression: Validation by real-time, quantitative RT-PCR. J. Biochem. Biophys. Methods 46:69-81.

38. Sneh, B. 1998. Use of non-pathogenic or hypovirulent fungal strains to protect plants against closely related fungal pathogens. Biotechnol. Adv. $16: 1-32$.

39. Song, P., Cai, Q., Skokut, M., Kosegi, B. D., and Petolino, J. F. 2001. Quantitative real-time PCR as a screening tool for estimating transgene copy number in WHISKERS-derived transgene maize. Plant Cell Rep. 20:948-954.

40. Vandesompele, J., De Preter, K., Pattyn, F., Poppe, B., Van Roy, N., De Paepe, A., and Speleman, F. 2002. Accurate normalization of real-time quantitative RT-PCR data by geometric averaging of multiple internal control genes. Published online by Genome Biol. doi:10.1186/gb-2002-37-research0034. 
41. Van Loon, L. C., Bakker, P., and Pieterse, C. M. J. 1998. Systemic resistance induced by rhizosphere bacteria. Annu. Rev. Phytopathol. 36:453-483.

42. Van Loon, L. C., and Van Strien, E. A. 1999. The families of pathogenesis-related proteins, their activities, and comparative analysis of PR-1 type proteins. Physiol. Mol. Plant Pathol. 55:85-97.

43. Villajuan-Abgona, R., Kageyama, K., and Hyakumachi, M. 1996. Biocontrol of Rhizoctonia damping-off of cucumber by non-pathogenic binucleate Rhizoctonia. Eur. J. Plant Pathol. 102:227-235.
44. Wen, K. 2004. Down-regulation of defense gene transcripts of Rhizoctonia solani-infected bean seedlings in response to inoculation with nonpathogenic fungi. M.S. thesis. McGill University, Montreal, Canada.

45. Xue, L., Brisson, L., and Jabaji-Hare, S. H. 1997. Activation of defense mechanisms in bean seedlings protected by non-pathogenic Rhizoctonia solani. (Abstr.) Phytopathology 87(suppl.):S106.

46. Xue, L., Charest, P. M., and Jabaji-Hare, S. H. 1998. Systemic induction of peroxidases, 1,3-beta-glucanases, chitnases, and resistance in bean plants by binucleate Rhizoctonia species. Phytopathology 88:359-365. 